\title{
Determinants of income from wheat and rape production in projection for 2020 in Poland
}

Konrad Jabłoński,

Aldona Skarżyńska,

Eukasz Abramczuk

Institute of Agricultural and Food Economics -

National Research Institute,

ul. Świętokrzyska 20,

00-002 Warszawa, Poland

E-mailkonrad.jablonski@ierigz.waw.pl
The study used the accounting data collected on 22 individual farms which at the same time cultivated winter wheat and winter rape in 2011 and 2013. The aim of the study was to determine the impact on the income from the cultivation of wheat and rape, predicted in prospect of 2020, taking into account the rate of change in yield and prices of wheat and rape and prices of means of agricultural production. Moreover, an attempt was made to determine the strength of influence of fluctuations in crop and sale price on deviations of income from the projection for 2020 . The calculations showed that, compared to the average of the studied years, in 2020 income from the cultivation of wheat will increase by $23.4 \%$, and that of rape by $58.4 \%$. However, increase in costs of cultivating wheat, faster than increase in outputs, will affect the profitability of production - by 2.0 percentage points, while for rape profitability it will increase by $7.7 \mathrm{pp}$. After taking into account the variability of the yield, income from cultivating wheat may vary by $\pm 22.5 \%$, and in the case of rape by as much as $\pm 41.5 \%$. Wheat and rape show much greater sensitivity to the variability of the sale price, and, as a result, income may vary by \pm 72.5 and $\pm 69.2 \%$, respectively. The study contributes to the development of research methods and can be used by farmers and decision-making centres.

Key words: projection, income, winter rape, winter wheat

\section{INTRODUCTION}

In Poland, a decrease in the utilized agricultural area (UAA) has been observed for a long time; from 2000 to 2010, it decreased by more than 2.3 million hectares, mainly due to the transfer of land for non-agricultural purposes (road infrastructure, housing construction). In the same period, the sown area decreased by 2.0 million hectares, mainly at the expense of reducing the area of cultivating sugar beet, potatoes and fodder plants ${ }^{1}$. At the same time, the area of crops, with a grow- ing share of wheat, remains at a constant level. The area of cultivating wheat in Poland, apart from periodic fluctuations, is about 1850 thousand ha. The area of growing rape is increasing. In 2000, it amounted to about 430 thousand ha, and in 2013 it was already 900 thousand ha (Skarżyńska, 2014).

The increase in the area of rape is related, among others, to the obligation to blend biofuel components into fuels imposed by the Act of 2 October 2003 on bio-components used in liquid fuels and liquid biofuels ${ }^{2}$, and another Act of 25 August 2006 on bio-components and liquid

Rocznik Statystyczny Rolnictwa 2011 [Statistical Yearbook of Agriculture 2011]. 2011. Warszawa: Główny Urząd Statystyczny. 393 p.

2 Dz. U. 2003 nr 199 poz. 1934 [Journal of Laws No. 199, item 1934: 2003]. Ustawa z dnia 2 października 2003 roku o biokomponentach stosowanych w paliwach cieklych i biopaliwach cieklych [The Act of 2 October 2003 on bio-components used in liquid fuels and liquid biofuels]. 2003. 
biofuels ${ }^{3}$. This Act enables registered individual farmers to produce biofuels, but in limited quantities (100 l/ha) or in the energy equivalent of another fuel, e. g. gas ${ }^{4}$. The introduced legislation helped to improve the profitability of cultivating rape relative to wheat. The trend favourable for the producers of rape strengthened after the Poland accession to the EU in 2004.

The $\mathrm{CO}_{2}$ emission requirements imposed by Directive 2009/28/EC of the European Parliament and of the Council of 23 April 2009 on the promotion of the use of energy from renewable sources ${ }^{5}$ resulted in further improvement in the relation of prices of rape to wheat. Favourable price relations further stimulated the systematic growth of rape cultivation area and increase of its share in the total sown area (Rosiak, 2008).

The Central Statistical Office publishes data on yield and crop of rape in selected European countries. Bearing in mind that between 2000 and 2010, except for periodic variations, the yield remained at a similar level, based on data on crops, the scale of the increase in rape cultivation area in individual countries can be assessed. In 2010, compared to 2000, the area of rape in the Czech Republic increased by $13.9 \%$, in Hungary over two times, and in Romania as much as 7 times. The high increase in the area of rape occurred also in the countries of Western Europe. In France, the crop acreage increased almost 3 times, in the United Kingdom by $62.3 \%$, and in Germany by $35.7 \%{ }^{6}$.

Wheat is a plant with large soil requirements. Studies show that on very good and good wheat soil, and very good rye soil wheat yields at a similar level. In contrast, the level of yield obtained on weaker soils is much lower (Podolska et al., 2005). Also rape requires good quality soil for optimum yield. Thus, competition between rape, meant for energy purposes, and wheat, grown for food purposes, will be greater and greater.

Farmers, guided mainly by economic considerations, will take decisions on the cultivation of wheat or rape with a view to the expected income.
The growing demand for biofuels, resulting from pressure on the environmental protection and the reduction of $\mathrm{CO}_{2}$ emissions, will stimulate improvement in profitability of growing rape. In contrast, the increase in the acreage of its cultivation will reduce the area of soil that can be designated for wheat, which will also result in pressure on the increase in its prices (Stanet et al., 2014).

The objective of the studies was to determine the effect on the level of income from the cultivation of winter wheat and winter rape, predicted for 2020, of the rate of change in prices of means of agricultural production and changes in yields and prices of products. The impact on deviations of income - from the level predicted for 2020 - of two factors determining its level, i. e. The yield and the price, was also assessed. The assessment also included the direction and the dynamics of changes of the production profitability, expressed as a percentage relation of the value of production to the costs of its production.

Not so much the absolute quantities, which should be approached with caution, as the direction of the changes taking place are crucially important in the conducted analyses. The results of economic forecasts should not be treated as error-free. First of all, they should inspire those concerned to take actions aimed at fixing the direction of development deemed beneficial or to counteract the direction of development, which is considered to be undesirable.

Agriculture is a sector of the economy particularly exposed to risk. Farmers take decisions based on knowledge without knowing the effects of those decisions. The study contributes to the development of research methods and can be used in practice. The results fill the information gap in terms of knowledge of future economic effects of wheat and rape cultivation. They have the possibility to be used in practice and are also important for farmers and decision-making centers, in accordance with the phrase "... prediction of tomorrow is essential to be able to act today."

\footnotetext{
Dz. U. 2006 nr 169 poz. 1199 [Journal of Laws No. 169, item 1199: 2006]. Ustawa z dnia 25 sierpnia 2006 r. o biokomponentach i biopaliwach ciektych [The Act of 25 August 2006 on bio-components and liquid biofuels]. 2006.

In terms of calorific value, corresponding to 100 litres of diesel oil.

Directive 2009/28/EC of the European Parliament and of the Council of 23 April 2009 on the promotion of the use of energy from renewable sources. 2009. European Council.

6 Own calculations based on: Rocznik Statystyki Międzynarodowej 2012 [International Statistics Yearbook 2012]. 2012. Warszawa: Główny Urząd Statystyczny. 614 p.
} 


\section{RESEARCH METHODS AND CONDITIONS}

The study used data characterizing winter wheat and winter rape, which was accumulated in the AGROKOSZTY system. Data collected under this system is related to the level of production and incurred expenditures and direct costs (Skarżyńska, 2007). It is a part of the research work carried out by the Institute of Agricultural and Food Economics - the National Research Institute in Warsaw. Information about the farms where the study was conducted came from the database of the Polish FADN. The selection of farms to the study on production activities was intentional - it included farms located all over the country, representing all area groups, but with a relatively large share of large-area farms. The studies were conducted in 2011 and 2013. For the purposes of this analysis, the study sample was a panel of 22 farms, the so-called "repeated in the years of study", which cultivated wheat and rape at the same time; thanks to this approach the results of the studied activities were not burdened with variations resulting from changes in sample farms.

The results of wheat and rape were presented as average for the panel of farms in the years of studying these activities, i. e. in 2011 and 2013, and on average in both years. The study included income (i. e. the value of potential commodity production from the cultivation of wheat and rape), costs and economic effects. The assessment measure of the obtained results was gross margin and income from activity (without subsidies). The method for calculating these categories is presented below:

Gross margin $=$ value of production - direct costs;

Income from activity $=$ value of production - total costs (direct + indirect).

In accounts for particular production activities, the value of production represents the production sum of main products and of marketable by-products. It is determined at market selling prices or at ex farm prices (i. e. for on-farm sale). In the case of crop production, it depends on the yield and the selling price for products. Various losses are deductible from output per ha (Skarżyńska, 2010).

Direct costs are cost elements which without doubt can be attributed to a given activity, their size has a proportional connection to the scale of production and they have a direct impact on output (in terms of quantity and value). An example would be the cost of seed material, mineral fertilizers or plant protection products. Indirect costs are costs common to the whole farm. They include, among others, the cost of electricity, diesel fuel, depreciation of fixed assets, current repairs of machinery and buildings, taxes. Indirect costs of farm production were allocated to wheat and rape according to the share of their value of production in the farm total value of production. Income from activity represents the value of production less direct and indirect costs. This income should provide the remuneration of unpaid labour input, land and own capital as well as management.

To assess the economic efficiency of production a profitability index of the activity was used. This index indicates what percentage of the production value expressed in current prices covers costs incurred to produce it. If the index is lower than 100, the production is unprofitable, whereas the more it exceeds 100, the higher the profitability is (Wadas, Sawicki, 2005):

$$
\frac{\text { Production profitability index }}{\text { of the activity, } \%}=\frac{\text { Production value }}{\text { Total costs }} \times 100
$$

In addition, the subject of assessment was the land productivity of the studied farms and their equipment in fixed assets. For this purpose, the land productivity (Fereniec, 1999) and the machinery intensity of farms (Ziętara, Olko-Bagieńska, 1984) were calculated:

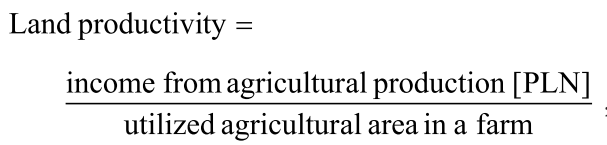

Machinery intensity =

value of machinery, tools and means of trasport $[\mathrm{PLN}]$. utilized agricultural area in a farm

For the farms from the studied sample a projection ${ }^{7}$ of the results for winter wheat and winter rape in prospect of 2020 was prepared. A basis for the projection was real data characterizing the studied activities on the average in the years of the study

Agriculture forecasting of future changes in production or economic situation is difficult because of high risk of changes in weather and farming conditions. That is why forecasts are named as projections. Projections have a conditional character and answer the questions what happens if conditions will be one or other. 
(2011 and 2013). This approach levelled random fluctuations of individual variables. Construction of the projection is based on an extrapolation of selected time series (Mirer, 2002; Jabłoński, 2012).

The corresponding time series with data of official statistics were assigned to each of the variables describing income and costs of wheat and rape production. This data covered the period from 1995 to 2013. The time series allowed the extrapolation into the future of the studied phenomena. Classic models of time trends were used to model them and to prepare projection of results. The time trend was separated using the analytical method, that is, by finding the trend function $f(t)$ ( $t$ is time) which best describes the changes of the phenomenon over time (Wasilewska, 2011). The analysis included seven functions: linear, polynomial of the second degree (quadratic), exponential, power, logarithmic, hyperbolic and linear-hyperbolic. For each of the series, the models of time trends were created in the following form:

$$
\begin{aligned}
& Y_{t}=\beta_{0}+\beta_{1} t+\varepsilon_{t}-\text { linear trend model, } \\
& Y_{t}=\beta_{0}+\beta_{1} t+\beta_{2} t^{2}+\varepsilon_{t}-\text { quadratic trend model } \\
& \text { (second degree polynomial), } \\
& Y_{t}=\beta_{0} e \beta_{1} t \cdot \varepsilon_{t}-\text { exponential trend model, } \\
& Y_{t}=\beta_{0}(t+2)^{\beta 1} \cdot \varepsilon_{t}-\text { power trend model, } \\
& Y_{t}=\beta_{0}+\beta_{1 \mathrm{ln}}(t+2)+\varepsilon_{t}-\text { logarithmic trend model, (8) } \\
& Y_{t}=B_{0}+\beta_{1} \frac{1}{t+2}+\varepsilon_{t}-\text { hyperbolic trend model, (9) } \\
& Y_{t}=\beta_{0}+B_{1} t+\beta_{2} \frac{1}{t+2}+\varepsilon_{t} \text { linear-hyperbolic trend } \\
& \text { model, }
\end{aligned}
$$

where $Y_{t}$ is the value of endogenous variable in time $t, t$ is the exogenous variable (time), takes integer values from 1 to $n, \beta_{0}$ is the absolute term, $\beta_{1}, \beta_{2}$ are the slopes of the function, $\varepsilon_{t}$ is the random element.

The parameters of all models were estimated using the classic method of the least squares. Separately for each of the analysed time series one of the trend functions was selected ${ }^{8}$. In most cases a linear trend model was selected. The selection was made on the basis of the coefficient of determination, $\mathrm{R}^{2}$, and experts' knowledge of the evolution of the studied phenomenon in time. On the basis of the selected models, the analysed phenomena, i. e. the variables characterizing the studied activities, were extrapolated for 2020 . This way, the projection in the average production and price conditions was made. In addition, possible deviations from the results of the projection for 2020, due to fluctuations in the yield and sale prices of wheat grain and rape seeds, were calculated 9 . The variability of these factors was determined on the basis of data from the CSO from 1995-2013, using the previous time trend models. Appropriate calculations were made using the following formula:

$$
V=\frac{\sqrt{\frac{\sum\left(Y-\hat{Y}^{2}\right.}{n}}}{\bar{Y}},
$$

where $V$ is the variability of the studied variable, $Y$ is empirical values of the variable, $\hat{Y}$ is the theoretical value of the variable resulting from the model, $\bar{Y}$ is the arithmetic mean of the value of the variable, $n$ is the number of observations.

Using the variability of yield and the price of wheat and rape observed in Poland between 1995 and 2013, it was possible to present the results of the projection as alternatives. Such an approach may be an indication of the extent of changes in the income situation of wheat and rape in prospect of 2020 .

\section{Characteristics of the studied farms}

In the studied sample of farms, both winter wheat and winter rape were grown on large surfaces (38.83 ha wheat in 2011 and 40.17 ha in 2013, and 23.71 and 29.67 ha rape in these years). It can be assumed that due to similar soil requirements they competed with each other for the area. The more so because the utility value of soil expressed in points was high (1.24-1.25 pt.). Taking the share in the value of total farm production as a measure of assessment, it is estimated that these were farms specializing in crop production. Its share clearly

8 For example, for the yield: for wheat a linear trend model was used, for rape a power trend model was used; and for the price: for wheat and rape a linear trend model was used.

9 Impact of the yield and the price was analysed independently. This was possible because the examination of the correlation between the yield and the price showed no significant relation between them. 
dominated the income, in 2011 it amounted to $93.1 \%$, and in 2013 it was $92.9 \%$.

In the utilised agricultural area (UAA), the share of the area occupied for the cultivation of winter wheat and winter rape jointly amounted to $65.2 \%$ in 2011 , and to $69.1 \%$ in 2013 . The total share of the value of production generated by the studied activities in the value of the total farm production stood at 55.8 and $61.6 \%$ in the respective years (Table 1). These results suggest that the role of wheat and rape, as a factor influencing the results of the whole farm, was very important.

It is estimated that the farms which qualified for the studied sample were development units. In 2013, compared to 2011, they increased the utilised agricultural area and the tractive force resources by $5.4 \%$ (i. e. $5.17 \mathrm{ha}$ ). It is proven by the machinery rate, that is, the total value of tractors, cars, machinery and equipment per 1 ha of agricultural area. In 2011, the median of this rate amounted to PLN 4669, and in 2013 to PLN 7457. This means that the value of machinery and tractors increased by $59.7 \%$ (i. e. by PLN 2788 per 1 ha of UAA). Considerable diversity was reported between the farms of the study sample, indicated by the gap, i. e. the difference between the maximum and the minimum level of the machinery rate. In 2013, however, this diversity was smaller, which means that the level of the machinery on farms became more even. This is proven by the relation of the gap to the median, which was 3.37 in 2011, and 2.54 in 2013.

The positive sign of the changes observed in 2013, compared to 2011, is also an increase in the productivity of the farm land (by 7.9\%) and, taking into account the results of individual farms, its more even level. The relation of the gap to the median amounted to 1.17 , while in 2011 to 2.04 (Table 1).

\section{RESULTS}

\section{Economic results of the production of wheat and} rape in the years of the study

On the average, in the sample of the farms participating in the study in 2011 and 2013, the income situation of winter wheat and winter rape was favourable. In 2013, the production results for both activities were better than in 2011, the yield of winter wheat increased by $6.0 \%$, and that of rape by as much as $51.2 \%$. There was deterioration in the sale prices. Farmers sold wheat cheaper by $2.2 \%$, and rape by $19.2 \%$. As a result of these

Table 1. Selected information about farms repeated in the years of the study, cultivating winter wheat and winter rape

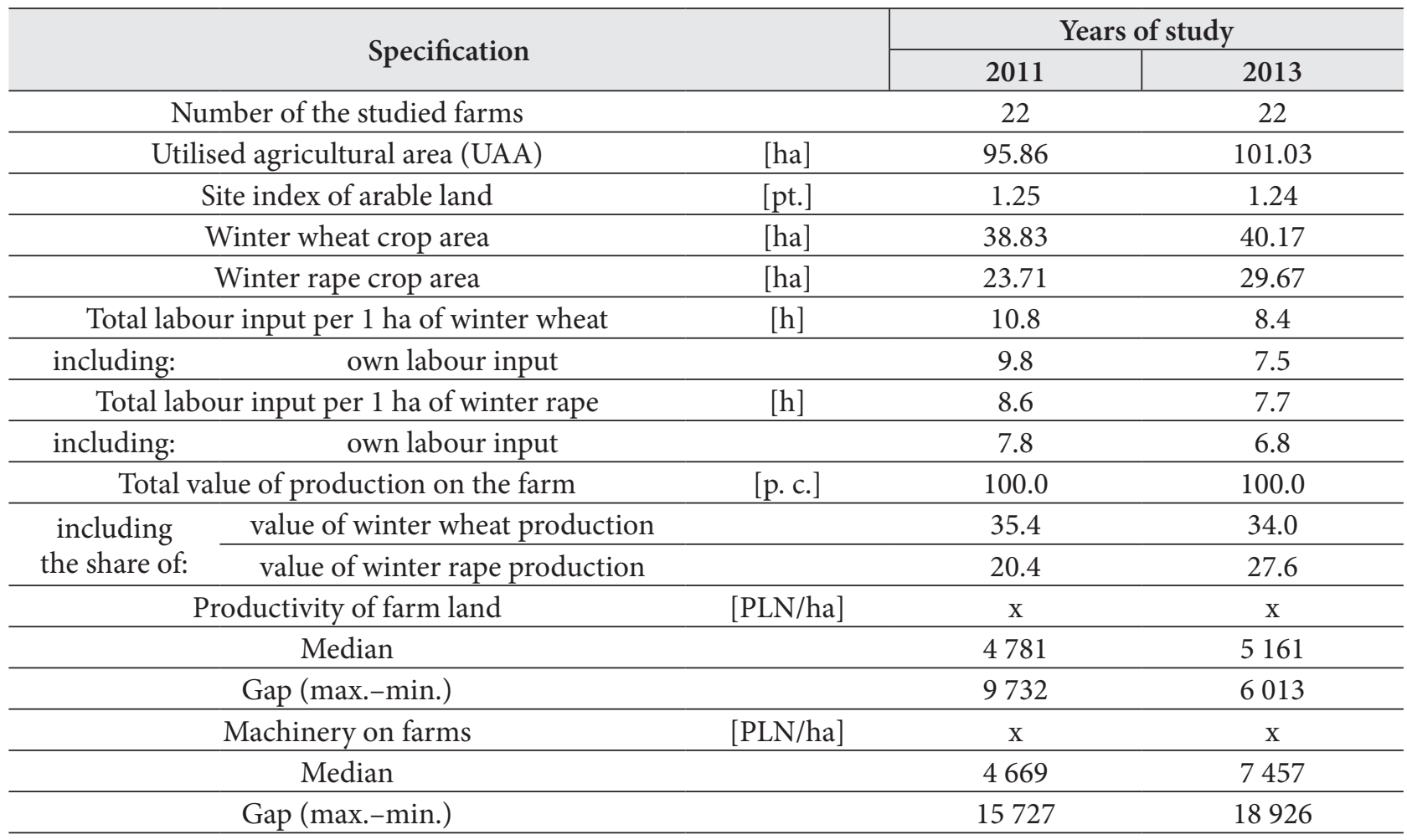


changes, in 2013, the value of production in both cases was higher by $3.2 \%$ for wheat and by $22.2 \%$ in the case of rape.

In 2013, compared to 2011, the direct costs of cultivation for both studied activities increased significantly. The increase in direct costs per 1 ha of winter wheat was $27.8 \%$ and that of winter rape was $39.8 \%$. However, due to the high yield of rape in 2013, the direct costs per $1 \mathrm{dt}$ of seeds were lower by $7.7 \%$, while in the case of wheat they grew by $20.7 \%$.

In 2013, the income available to the farmer, for both wheat and rape, was lower than in 2011 - by 22.9 and $16.4 \%$, respectively. The decrease in the income resulted from the increase in total costs (direct and indirect) for wheat by $15.7 \%$, and for rape by $40.3 \%$ (Table 2 ).

Despite significant fluctuations in the value of production, costs and income, observed in 2011 and 2013, the income for both winter wheat and winter rape, on the average for these two years was similar. The difference in the generated income was only $1 \mathrm{PLN} / \mathrm{ha}$. However, the production of rape was more cost-intensive, which is proven by the level of both direct and indirect costs. Especially direct costs, which reflect the level of incurred expenditures, were clearly higher for rape by $19.3 \%$ on the average in the years of the study. As a result, the relation of direct costs to the gross margin generated was more favourable for wheat: it amounted to $44.6 \%$, while for rape it was $52.3 \%$. This means that wheat is characterized by greater cost competitiveness. It means that generating PLN 1 of the gross margin of winter wheat costs PLN 0.45 and for winter rape it costs PLN 0.52.

After analysing the production profitability index of the activity (expressed as the relation of the production value to total costs), it can be concluded that for winter wheat and rape it developed at a similar level. On the average, in the years of the study, the profitability index for winter wheat was $139.3 \%$, while for rape it was $135.7 \%$.

\section{Projection of results for 2020}

Public statistics in the last few years indicate a higher growth rate of prices of production means for agriculture (input prices) in comparison to the growth rate of prices for sold agricultural products. Between

Table 2. Costs and economic results of the production of winter wheat and winter rape in the years of the study

\begin{tabular}{|c|c|c|c|c|c|c|}
\hline \multirow{3}{*}{ Specification } & \multicolumn{3}{|c|}{ Winter wheat } & \multicolumn{3}{|c|}{ Winter rape } \\
\hline & \multicolumn{2}{|c|}{ Years of study } & \multirow{2}{*}{$\begin{array}{l}\text { On the av- } \\
\text { erage in } \\
\text { the years of } \\
\text { study }\end{array}$} & \multicolumn{2}{|c|}{ Years of study } & \multirow{2}{*}{$\begin{array}{l}\text { On the av- } \\
\text { erage in } \\
\text { the years of } \\
\text { study }\end{array}$} \\
\hline & 2011 & 2013 & & 2011 & 2013 & \\
\hline Yield of grain/seeds & 60.3 & 63.9 & 62.1 & 24.2 & 36.6 & 30.4 \\
\hline \multirow[t]{2}{*}{ Sale price } & 74.58 & 72.92 & 73.75 & 183.40 & 148.14 & 165.77 \\
\hline & \multicolumn{3}{|c|}{ PLN per 1 ha } & \multicolumn{3}{|c|}{ PLN per 1 ha } \\
\hline Total value of production & 4522 & 4667 & 4594 & 4430 & 5415 & 4922 \\
\hline Total direct costs & 1244 & 1590 & 1417 & 1411 & 1972 & 1691 \\
\hline seed material & 205 & 244 & 224 & 124 & 159 & 142 \\
\hline mineral fertilizers & 683 & 884 & 784 & 858 & 1237 & 1048 \\
\hline plant protection products & 310 & 383 & 346 & 372 & 463 & 417 \\
\hline Gross margin & 3278 & 3077 & 3177 & 3019 & 3443 & 3231 \\
\hline Total indirect costs & 1815 & 1949 & 1882 & 1610 & 2265 & 1937 \\
\hline farming costs and taxes & 929 & 905 & 917 & 787 & 1047 & 917 \\
\hline depreciation & 550 & 694 & 622 & 522 & 750 & 636 \\
\hline cost of external factors & 336 & 350 & 343 & 300 & 468 & 384 \\
\hline Income from activity & 1463 & 1128 & 1295 & 1409 & 1178 & 1294 \\
\hline Total costs (direct + indirect $)$ & 3059 & 3539 & 3299 & 3020 & 4237 & 3629 \\
\hline Total direct costs per $1 \mathrm{dt}$ of grain/seeds [PLN/dt] & 20.63 & 24.90 & 22.82 & 58.42 & 53.95 & 55.73 \\
\hline Total costs per $1 \mathrm{dt}$ of grain/seeds & 50.72 & 55.41 & 53.13 & 125.06 & 115.91 & 119.55 \\
\hline Profitability index & 147.8 & 131.9 & 139.3 & 146.7 & 127.8 & 135.7 \\
\hline
\end{tabular}


1995 and 2013, the cumulative price scissors index amounted to $75.2 \%$. This means that the prices of production means for agriculture (input prices) were rising almost $25 \%$ faster than the prices of agricultural products sold (output prices).

What changes can be expected in the profitability of wheat and rape production by 2020 ? The applied projection method - by extrapolating the trend observed in the past - allowed determining the expected direction of changes on the side of income and the cost of production. It is expected that in the production and price conditions resulting from the long-term trend, the annual increments of the production value (income) of cultivating winter wheat may be in the range of $3.4-3.8 \%$ (with the increments of yield at the level of $1.2 \%$, and the prices of grain from 2.2 to $2.6 \%$ ), while the production costs (total direct and indirect) will increase at a rate of $3.4-4.2 \%$.

Due to larger increments in costs than income, in 2020 - compared to the average in the years of the study - wheat production costs will increase by $29.7 \%$ and income by $27.9 \%$. In consequence, the economic efficiency of wheat production will deteriorate - the profitability index will decline by 2.0 percentage points (it will amount to $137.3 \%$ ). This means that the production will be produced in an overly expensive way. Despite the improvement in the production results, the unit cost of $1 \mathrm{dt}$ of grain will increase. It is expected that in 2020, compared to the average of the years of the study, it will be higher by $19.7 \%$, whereas the sale price of grain will increase by only $18.1 \%$. Even though it is estimated that in 2020 in the studied farms income without subsidies obtained from 1 ha of winter wheat will exceed the level from the years of the study by $23.4 \%$ (it may amount to PLN 1598) as shown in Table 3.
The results of the projection prepared for 2020 allow us to look optimistically at the economic situation of rape in the coming years. It should be expected that the value of production, that is, output from the cultivation of 1 ha of rape, will be increasing annually from 3.9 to $4.8 \%$ (with the increments of yield in the range of $1.0-1.2 \%$, and the price of seed from 2.9 to $3.5 \%$ ) and in 2020 - compared to the average of 2011 and 2013 - it will reach the level higher by $37.5 \%$. Total costs, with annual increments from 3.5 to $4.2 \%$, could increase by $30.1 \%$. This means that, in prospect of 2020 , dynamics of growth of the value of production stronger by $7.4 \mathrm{pp}$ than the costs should be expected. As a result, the profitability index will increase by $7.7 \mathrm{pp}$ and amount to $143.4 \%$.

Under the conditions set out by the projection model, it can be expected that in 2020, compared to the years of the study, the cost of producing $1 \mathrm{dt}$ of rape seeds will increase by $20.6 \%$, and the price of seeds by $24.7 \%$. In this situation, income from activity calculated for $1 \mathrm{dt}$ may be higher by $46.9 \%$ (it will amount to PLN 62.6 in comparison with PLN 42.6 in the years of the study). Income from the cultivation of 1 ha of rape in 2020 - compared to the average of 2011 and 2013 - could rise by as much as $58.4 \%$. Its level ( $2050 \mathrm{PLN} / \mathrm{ha}$ ) will be higher than the income from winter wheat (1 $598 \mathrm{PLN} / \mathrm{ha}$ ) by $28.3 \%$.

The presented projection for 2020 was made in average production and price conditions resulting from the long-term trends. However, yields and prices are subject to some fluctuations. Yielding of plants is largely dependent on weather conditions. Random events, such as droughts or floods, are difficult to predict, and their impact on the size of yield can be significant. This is an important issue because in recent years

Table 3. Results of the projection of winter wheat and winter rape for 2020 (in current prices)

\begin{tabular}{|c|c|c|c|}
\hline \multirow{2}{*}{ Specification } & & \multicolumn{2}{|c|}{ Projection for 2020} \\
\hline & & Winter wheat & Winter rape \\
\hline Yield of grain/seeds & {$[\mathrm{dt} / \mathrm{ha}]$} & 67.3 & 32.7 \\
\hline \multirow[t]{2}{*}{ Sale price of grain/seeds } & {$[\mathrm{PLN} / \mathrm{dt}]$} & 87.06 & 206.80 \\
\hline & & \multicolumn{2}{|c|}{ Per 1 ha of crop, in PLN } \\
\hline Value of production & & 5878 & 6769 \\
\hline Total costs & & 4281 & 4719 \\
\hline Income from activity & & 1598 & 2050 \\
\hline Production profitability index (production value to total costs) & {$[\%]$} & 137.3 & 143.4 \\
\hline
\end{tabular}


the weather has been very different from the one considered "normal" for decades. Losses of yields due to adverse weather events become one of the main problems (Tubiello et al., 2007). Together with climate change, we also observe greater environmental impact of agriculture such as, e. g. increased erosion (Olesen et al., 2011). Prices of agricultural products and prices of products needed for agricultural production (mineral fertilizers, plant protection products, etc.) are also subject to fluctuations. Sale prices of agricultural products are characterized by a particularly high volatility, since they are largely dependent on the demand and supply situation in the domestic and foreign markets.

Testing the course of the time series of wheat buying-in prices for the years 2001-2014 indicates the presence of all four main variability components, i. e. development trend, cyclical fluctuations, seasonal fluctuations and accidental fluctuations. Cyclical fluctuations become visible as recurring oscillations around the trend lines. Another phenomenon disclosed in the case of the time series of wheat buying-in prices is overlaying different kinds of variability. Cyclical fluctuations run around the trend line, on the other hand, seasonality is disclosed as deviations in respect of the so-called trend-cycle. The outlined development trend is determined substantially by an inflationary factor (Skarżyńska et al., 2014).

Fluctuations in the yield and prices, in consequence, have an impact on economic results. Development of a reliable projection of these results is therefore impossible, however, the limits of variations can be predicted and the direction of changes in the achieved results can be observed. Therefore, it was tested how the level of income from the production of wheat and rape, predicted in prospect of 2020, may be affected by fluctua- tions in the factors determining it. This test was limited to two factors, i. e. the yield and the price. Their impact on the level of income was studied independently, assuming that other variables (characterising costs of cultivation) are subject to changes resulting from long-term trends. Variability of yield and price was determined on the basis of data from the CSO in 1995-2013.

The calculation results presented in Table 4 show much greater variability in rape crop than in wheat (2.1 times). This means that rape is a plant reacting much more strongly to the conditions of cultivation than wheat. The reflection of this situation is possible changes in the level of income. Within the variability of the yield, income from the cultivation of 1 ha of rape predicted for 2020 may change by \pm 851 PLN. This value is 2.4 times greater than for wheat, for which income may vary by \pm 360 PLN. In percentage terms, the variability of income for rape may be by 19.0 pp greater than for wheat (41.5\% compared to $22.5 \%$ ).

Price variability observed between 1995 and 2013 was similar in the case of wheat and rape, amounted to 19.8 and $20.9 \%$, respectively, and was significantly greater than the variability of yields. This has a clear impact on economic results. In prospect of 2020 , income from activity may vary due to variability in prices by $\pm 72.5 \%$ (PLN 1158) for wheat and by $\pm 69.2 \%$ (PLN 1417) for rape. Deviations from the expected income can, therefore, be very large for both wheat and rape (Table 4).

If the variations in yield and price are taken into account, profitability in quotient terms (ratio of the production value to total costs) in prospect of 2020 is also likely to be subject to significant changes. With an increase in yield by $4.1 \mathrm{dt}$ (resulting from variations), the profitability index for wheat (compared to the value resulting from

Table 4. Impact of the variability of yield and price of wheat and rape, observed from 1995 to 2013, on deviations from the projected results for 2020

\begin{tabular}{|c|c|c|c|c|c|c|}
\hline \multirow{2}{*}{\multicolumn{2}{|c|}{ Specification }} & \multirow{3}{*}{$\begin{array}{c}\text { Variability acc. } \\
\text { to CSO (\%) of } \\
\text { yield/price }\end{array}$} & \multicolumn{4}{|c|}{ Deviation from the projection for 2020} \\
\hline & & & \multirow{2}{*}{$\begin{array}{c}\text { Yield } \\
{[\mathrm{dt}]}\end{array}$} & \multirow{2}{*}{$\begin{array}{c}\text { Price } \\
{[\mathrm{PLN}]}\end{array}$} & \multicolumn{2}{|c|}{ Income from activity } \\
\hline & & & & & {$[\mathrm{PLN}]$} & {$[\%]$} \\
\hline \multirow{2}{*}{ Winter wheat } & Yield & 6.1 & \pm 4.1 & \pm 0.00 & \pm 360 & \pm 22.5 \\
\hline & Price & 19.8 & \pm 0.0 & \pm 17.20 & \pm 1158 & \pm 72.5 \\
\hline \multirow{2}{*}{ Winter rape } & Yield & 12.6 & \pm 4.1 & \pm 0.00 & \pm 851 & \pm 41.5 \\
\hline & Price & 20.9 & \pm 0.0 & \pm 43.30 & \pm 1417 & \pm 69.2 \\
\hline
\end{tabular}


the projection) can be higher by $8.4 \mathrm{pp}$, and with a possible increase in price by PLN 17.20, it can rise by as much as $27.1 \mathrm{pp}$. In the opposite situation (drop in yield or price), the profitability of production will decrease by 8.4 and $27.1 \mathrm{pp}$, respectively. What is important, even in such a situation cultivation of wheat will be profitable (Fig. 1).

According to the results of the projection for 2020, profitability of cultivating winter rape will amount to $143.4 \%$. It can be even higher under favourable production conditions (increase in yield by $4.1 \mathrm{dt}$ ) - by $18.0 \mathrm{pp}$, or price conditions (increase by PLN 43.30) - by 30.0 pp. At the same time, the calculations carried out indicate that under unfavourable production or price conditions the profitability index will be lower by 18.0 and $30.0 \mathrm{pp}$, respectively. Like in the case of wheat, even after taking into account possible decrease in yield or price, rape will remain a profitable activity (Fig. 2).

When comparing the profitability of wheat and rape in prospect of 2020 in terms of variants, it can be noticed that the production of rape is almost always more profitable. Only with low production results cultivation of wheat may prove to be more profitable.

Projections allow diagnosing future conditions under which the actions taken will be implemented. However, risk and uncertainty are inescapable factors in agriculture which require careful management. Farmers face production risks from the weather, crop and livestock performance, and pests and diseases, as well as institutional, personal and business risks (Hardeker et al., 1997; Moschini, Hennessy, 2000; Just, Pope, 2002; Hardeker et al., 2015). Thus, it may be stated that in the case of agriculture projection is an essential element of effective and efficient running of a farm. It also plays an important role in determining the consequences of decisions, i. e. expected benefits and costs to be incurred. The more information a farmer is going to have about possible effects of decisions, the more rational his decisions are.

\section{CONCLUSIONS}

In 2011 and 2013, in a sample of 22 individual farms cultivating at the same time winter wheat
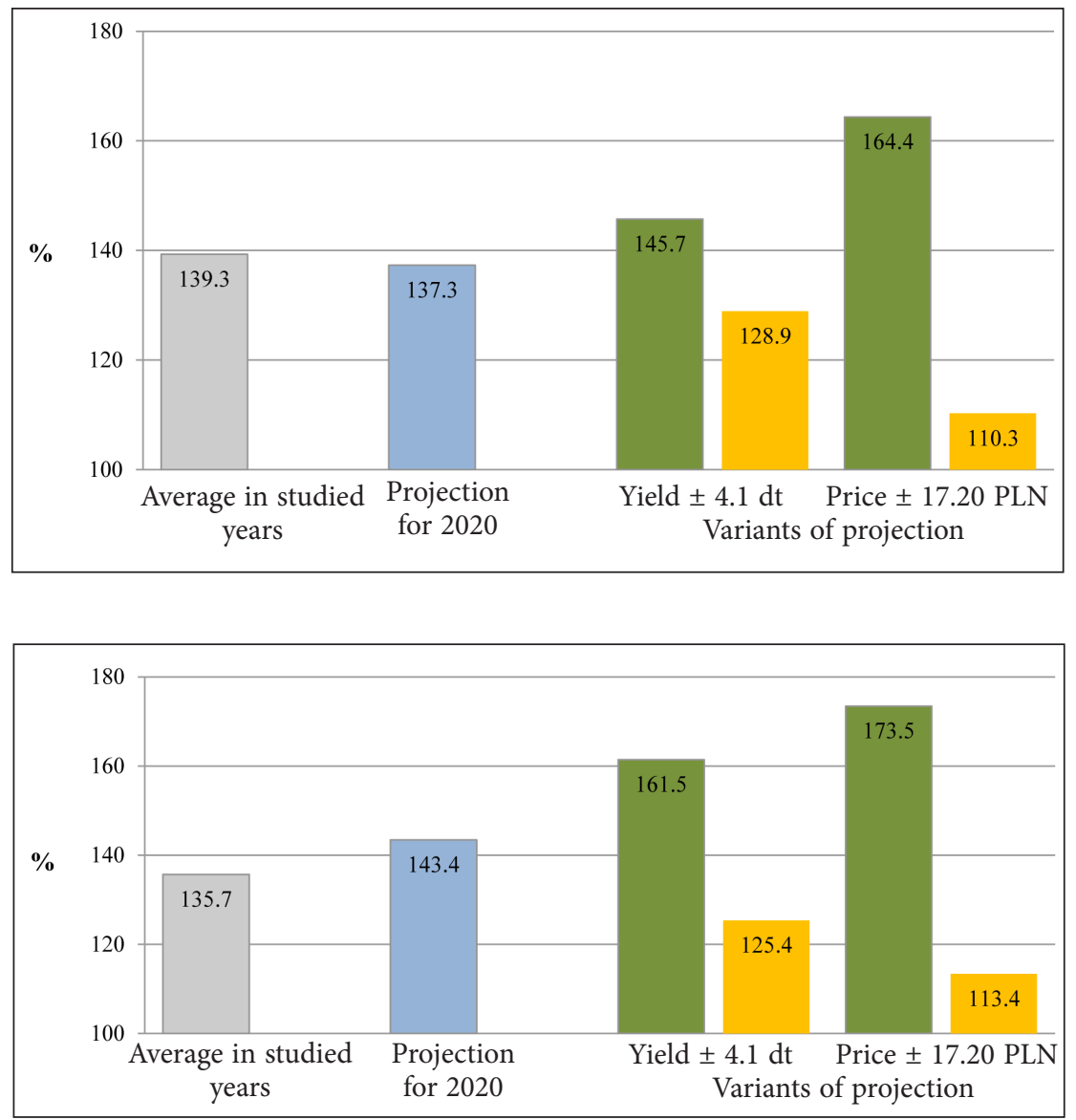

Fig. 1. Production profitability index of winter wheat in prospect of 2020

Fig. 2. Production profitability index of winter rape in prospect of 2020 
and winter rape, economic results of both activities were similar. On the average, in the years of the study, the profitability of wheat production was by 3.6 percentage points higher. Income from the cultivation of 1 ha was for both studied plants at almost the same level. At the same time, cultivation of rape was more cost-intensive, and total costs were by $10.0 \%$ higher than those for wheat.

According to the projection prepared under average conditions, i. e. resulting from the longterm trend, until 2020, improvement in production and price results for both winter wheat and winter rape is expected.

The annual growth rate of wheat yield will be at the level of $1.2 \%$, and prices of grain will be in the range between 2.2 and 2.6\%. Annual increments of production costs may be from 3.4 to $4.2 \%$. Under these conditions, production of wheat will be characterized by a stronger growth rate of costs than income, therefore, compared to the output data for the projection, a decrease in the profitability of production by $2.0 \mathrm{pp}$ is expected.

Projection results indicate that in prospect of 2020 winter rape yield will be increasing by about $1 \%$ annually, the price of seeds by about $3 \%$, and the costs of production in the range of $3.5-4.2 \%$. The result will be stronger dynamics of growth of income than costs and an increase in profitability of its production by $7.7 \mathrm{pp}$.

However, there might be annual variations from these general trends, which cannot be predicted, and their impact on production and economic results of wheat and rape could be significant. Studies show that rape is characterized by a very high sensitivity to fluctuation in yield and sale price. This means that under favourable production and price conditions a significant increase in income can be expected, but at the same time its cultivation is subject to very high risk.

The results of research indicate that wheat - in comparison with rape - is less sensitive to fluctuations in production results. Due to the variability of yield, income from 1 ha of wheat can vary by $\pm 22.5 \%$. This is by 19.0 pp less than in the case of rape. Wheat, however, shows a high sensitivity to variation in the sale price and income fluctuations can be by 3.3 pp greater than those for rape.

Projection of results for 2020 and its alternatives show the benefits, but also possible risks.
This knowledge is still very useful, it reduces uncertainty and may contribute to an increase in the accuracy of decisions, and thus to the elimination of losses, which might occur in different circumstances.

Received 3 June 2015 Accepted 7 December 2015

\section{REFERENCES}

1. Fereniec J. 1999. Ekonomia i organizacja rolnictwa [Economics and Organization of Agriculture]. Warszawa: Wydawnictwo Key Text. 493 p.

2. Hardaker J. B., Huirne R. B. M., Anderson J. R., Lien G. 2015. Coping with Risk in Agriculture. Applied Decision Analysis. 3rd Edition. CABI. 288 p.

3. Hardeker J. B., Huirne R. B. M., Anderson J. R. 1997. Coping with Risk in Agriculture. Oxon, United Kingdom: CAB International. $352 \mathrm{p}$.

4. Jabłoński K. 2012. Income projection method. In: Projection of Income in the Mid-term Perspective for Selected Agricultural Products. Multi-Annual Programme 2011-2014 No. 55.1. Warsaw: IAFENRI. P. 20-32.

5. Just R. E., Pope R. D. (ed.). 2002. A Comprehensive Assessment of Risk in U. S. Agriculture. Boston: Kluwer Academic Publishers. 586 p.

6. Mirer T. W. 1995. Economic Statistics and Econometrics. 3rd Edition. Prentice-Hall. 464 p.

7. Moschini G., Hannessy D. A. 2000. Uncertainty, risk aversion and risk management for agricultural producers. In: Handbook of Agricultural Economics. Amsterdam: Elsevier Science Publishers. 101 p.

8. Olesen J. E., Trnka M., Kersebaum K. C., Skjelvåg A. O., Seguin B., Peltonen-Sainio P., Rossi F., Kozyra J., Micale F. 2011. Impacts and adaptation of European crop production systems to climate change. European Journal of Agronomy. No. 34.

9. Podolska G., Stankowski S., Podolski B. 2005. Plonowanie i wartość technologiczna ziarna pszenicy ozimej w zależności od warunków glebowych [Yield and technological value of winter wheat grain depending on soil conditions]. Pamiętnik Puławski. Zeszyt 139. P. 189-197.

10. Rosiak E. 2008. Krajowy rynek rzepaku w sezonie 2007/08 [Domestic oilseed market in the season of 2007/08]. Rośliny Oleiste. Zeszyt 1. P. 9-18.

11. Skarżyńska A., Abramczuk Ł., Augustyńska-Grzymek I., Czułowska M., Idzik M., Jabłoński K., Żekało M. (Skarżyńska A., scientific editor). 2014. Nadwyżka bezpośrednia $z$ wybranych produktów rolniczych $w 2013$ roku oraz projekcja dochodów na 2020 rok [Gross Margin from Selected Agricultural Products in 2013 and Projected Income for 2020]. Multi-Annual Programme 2011-2014. No. 105. Warszawa: IERiGZ̈-PIB. 235 p. 
12. Skarżyńska A. 2007.Założenia metodyczne [Methodological Assumptions]. Zagadnienia Ekonomiki Rolnej. Dodatek do zeszytu 3/2007. Warszawa: IERiGŻ-PIB. P. 5-16.

13. Skarżyńska A., Abramczuk Ł., Augustyńska-Grzymek I., Czułowska M., Idzik M., Jabłoński K., Żekało M. (Skarżyńska A., scientific editor). 2014. Projection of Income for the Selected Agricultural Products for 2020. Multi-Annual Programme 2011-2014. No. 105.1. Warsaw: IAFE-NRI. 134 p.

14. Skarżyńska A. 2010. Economic Results of Selected Agricultural Products in 2005-2008. Multi-Annual Programme 2005-2009. No. 176.1. Warsaw: IAFENRI. 114 p.

15. Stanet K., Stasiak-Panek J., Kupczyk A. 2014. Stan aktualny i perspektywy bioetanolu w Polsce [Current state and prospects of bioethanol in Poland]. Wieś Jutra. No. 4. P. 42-44.

16. Tubiello F. N., Soussana J. F., Howden S. M. 2007. Crop and Pasture Response to Climate Change. PNAS. $104 \mathrm{p}$.

17. Wadas W., Sawicki M. 2005. Ocena opłacalności produkcji ziemniaków wczesnych w warunkach środkowo-wschodniej Polski [Estimation of early potato profitability in the mid-eastern Poland conditions]. Pamiętnik Puławski. Zeszyt 139. P. 289-297.

18. Wasilewska E. 2011. Statystyka opisowa od podstaw [Descriptive Statistics From Basis]. Warszawa: SGGW. 424 p.

19. Ziętara W., Olko-Bagieńska T. 1984. Zadania z analizy działalności gospodarczej i planowania w gospodarstwie rolniczym [From the Analysis of Economic Activity and Planning in a Farm]. Warszawa: PWRiL. 167 p.

\section{Konrad Jablonski, Aldona Skarzynska, Lukasz Abramczuk}

\section{KVIEČIŲ IR RAPSŲ AUGINIMO EKONOMINIS EFEKTYVUMAS IR J! LEMIANTYS VEIKSNIAI: PROGNOZĖ IKI 2020 METŲ}

\section{Santrauka}

Tyrimo tikslas - nustatyti kviečių ir rapsų auginimo pajamų lygi lemiančius veiksnius, pateikti prognozes iki $2020 \mathrm{~m}$. atsižvelgiant ị derliaus ir žemès ūkio produkcijos kainų pokyčius. Išnagrinėjus 22 ūkininkų ūkių, auginančių žieminius kviečius ir žieminius rapsus, 2011 ir 2013 m. ekonominius rodiklius, nustatyta, kad jų rezultatai buvo panašūs. Pajamos iš 1 ha žieminių kviečių ir žieminių rapsų taip pat mažai skyrèsi. Ilgalaikè prognozė (iki 2020 m.) rengta remiantis vidutinemis augimo sąlygomis, numatytos pajamos už rapsus ir kviečius, kurias lemia produkcija bei palankios rinkos kainos. Prognozuojama, kad žieminių kviečių gamybos išlaidos augs greičiau negu pajamos, tačiau, palyginti su prognozuojamais rezultatais, gamybos pelningumas sumažès tik 2,0 proc. punktais. Auginant žieminius rapsus numatoma priešinga tendencija - gamybos pelningumas išaugs 7,7 proc. punkto. Tyrimai parodè, kad pajamoms už rapsus būdingi didesni svyravimai, palyginti su kviečių derlingumu ir pardavimo kainomis. Tai reiškia, kad esant palankioms gamybos ir kainų sąlygoms galima tikètis reikšmingo pajamų augimo, tačiau labai tuo pasikliauti būtų itin rizikinga. Taigi prognozès iki 2020 m. pateikia galimą naudą ir riziką.

Raktažodžiai: prognozè, pelningumas, žieminiai rapsai, žieminiai kviečiai 